> Innlegg på inntil $\mathbf{4 0 0}$ ord lastes opp i http://mc.manuscriptcentral.com/tidsskriftet.

Redaksjonen forbeholder seg retten til å foreta redaksjonelle endringer.

Forfattere av vitenskapelige artikler har tilsvarsrett (jf. Vancouver-gruppens regler).

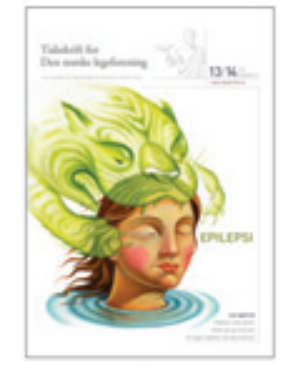

\section{Epilepsi og religion}

Takk for artikkelen om epilepsi og religion i Tidsskriftet nr. 13-14/2011 (1), som var interessant og lærerik (1). Forfatterne viser at temporallappsepilepsi i noen tilfeller er fulgt av sterke religiøse forestillinger. De gir også en troverdig gjennomgang av en rekke kjente profeter, helgener og sektgrunnleggere som sannsynligvis led av slik sykdom. Eksempler som nevnes er profeten Esekiel, Buddha, apostelen Paulus, Muhammed, Jeanne d'Arc og grunnleggeren av kvekersamfunnet George Fox. Til og med Bjørnstjerne Bjørnsons Vis-Knut led av temporallappsepilepsi.

Dessverre trekker ikke forfatterne den nærliggende og spenstige konklusjonen at moderne behandling med antiepileptika sannsynligvis ville ha kunnet forebygge mye religiøs galskap. Det er også dypt tragisk at flere hundre tusen kvinner med epilepsi ble brent som hekser av religiøse fanatikere. Sannsynligvis er diagnostikk og behandling av epilepsi noe av forklaringen på at det per $2011 \mathrm{i}$ den moderne verden praktisk talt ikke finnes profeter eller religiøst opplyste personer som tas seriøst. Jeg mener det er en svakhet ved artikkelen at forfatterne av ukjente grunner ser ut til å skygge unna dette viktige aspektet. Den vitenskapelige tenkeren bør våge å ta den kritiske diskusjonen og konsekvensene av sine funn helt ut, også dersom man tenker at resultatene kan virke støtende på noen.

\section{Tor K. Larsen}

Stavanger universitetssjukehus

Tor K. Larsen (f. 1960) er overlege og spesialist i psykiatri og professor II ved Universitetet i Bergen.

Ingen oppgitte interessekonflikter.

\footnotetext{
Litteratur

1. Nakken KO, Brodtkorb E. Epilepsi og religion. Tidsskr Nor Legeforen 2011; 131: 1294-7.
}

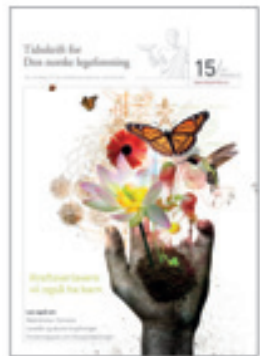

\section{Legemiddelindustriens politiske korrekthet}

Administrerende direktør i Legemiddelindustrien (LMI) Karita Bekkemellem kommer i Tidsskriftet nr. 15/2011 med sin begrunnelse for at leger ikke lenger skal sponses av industrien (1). Foreningens medlemmer skal ikke ha anledning til å betale helsepersonells reiser til fagkongresser i utlandet. Argumentet er at det er blitt stilt kritiske spørsmål til om det er industriens oppgave å «sponse» etterutdanning for leger og at dette kan skape uheldige bindinger mellom firmaer og leger.

Det er selvfølgelig helt i orden å stille spørsmål ved dette, men samtidig undrer man seg over tidspunktet dette blir tatt opp til diskusjon og avgjort i Legemiddelindustrien. Direktøren forklarer at det er sterk konkurranse innen medisinsk forskning og økte kostnader, slik at legemiddelforskningen går ned. Dette tolker jeg til at en del av inntjeningsgrunnlaget faller bort slik at overskuddet minsker. Hvorfor sier da ikke direktøren direkte at et viktig argument fra Legemiddelindustrien for innføringen av dette «forbudet mot sponsing» er økonomisk innsparing for foreningens medlemmer? Kan det tenkes at medlemmene har kommet frem til at det å invitere helsepersonell til internasjonale kongresser ikke er lønnsomt? Kan det være at det ikke er samarbeidet som er problematisk, men at trange økonomiske kår er hovedgrunnen?

Jeg har forstått det slik at Legemiddelindustrien fremdeles skal ha anledning til å invitere til egne arrangerte møter internasjonalt og nasjonalt. Legene vil med andre ord fortsatt kunne inviteres til møter tilrettelagt av industrien selv. Det skriver ikke direktøren noe om, for det passer ikke inn $\mathrm{i}$ hennes bilde. De store internasjonale kongressene planlegges og arrangeres uavhengig av industrien, mens industrien bidrar økonomisk med utstillinger, reklame og egne symposier. På disse kongressene har den enkelte lege selv mulighet til å velge temaer og fagområder av størst interesse og potensial for ny viten. Hvis hovedgrunnen er at man skal minske det problematiske samarbeidet, hvorfor er det da disse kongressene som kuttes - ikke møtene arrangert av industrien selv?

Jeg er selvfølgelig enig $i$ at det er arbeidsgivers oppgave å sikre god kvalitet på behandlingen gjennom etterutdanning av leger. Legeforeningen er i så måte en viktig tilrettelegger og premissleverandør. Jeg deler imidlertid ikke Legemiddelindustriens bekymring for nedgangen i klinisk legemiddelforskning i helseforetakene. Det er i stor grad industriens eget valg å flytte mye av forskningen til lavkostland for å minske utgiftene og dermed øke aksjonærenes overskudd. Kan det være slik at de nye selvpålagte reglene innført av Legemiddelindustrien like mye er del av denne strategien?

\section{Bjørn Moum}

Oslo universitetssykehus

Bjørn Moum (f. 1952) er professor, leder av Seksjon forskning og utvikling ved Gastromedisinsk avdeling og spesialist i fordøyelsessykdommer.

Ingen oppgitte interessekonflikter.

Litteratur

1. Bekkemellem K. Åpenhet om samarbeid og deling av kunnskap. Tidsskr Nor Legeforen 2011; 131. 1528.

\section{Korrupt offentlig saksbehandling?}

I Olav Hamrans artikkel Et lite, korrupt gammelt vesen - apotekloven av 2001 i Tidsskriftet nr. 13-14/2011 (1) er det vanskelig å finne dekning for ordet «korrupt». Kan det være der Hamran omtaler Strøm-utvalgets innstilling (2)? Han viser til kritikk av den tidligere praksis for etablering av apotek og tildeling av bevilling og skriver: «Det ble pekt spesielt på at 14 ansatte i Helsedirektoratet/-tilsynet hadde fått apotekerbevilling eller blitt ansatt som sykehusapotekere.»

Som nestleder og senere toppsjef $i$ det meste av den aktuelle perioden vil jeg peke på at Hamran burde, som Strøm-utvalget i sin innstilling, opplyst om at de 14 sakene fant sted over et tidsrom på 15 år - ut fra et totalt antall saker i perioden på omkring 300. Saksbehandlingen skjedde i tråd med 
gjeldende lovgivning. Bevillingssakene ble vurdert $i$ et rådgivende utvalg med representanter fra ledere og ansatte i apotek, og avgjørelsen ble fattet av helsedirektøren. I saker med interne søkere ble saksbehandlingen forankret $\mathrm{i}$ vår juridiske avdeling i stedet for i fagavdelingen.

Heldigvis fikk vi i Helsedirektoratet/-tilsynet regelmessig dyktige søkere til våre stillinger i apotek- og legemiddelforvaltningen. Det ville være urimelig å kreve at disse medarbeiderne skulle ha yrkesforbud mot å søke andre stillinger i fagfeltet og slik bli satt $\mathrm{i}$ en uheldig situasjon ved å arbeide hos oss.

Det er alvorlig å beskylde saksbehandlingen i daværende Helsedirektoratet/-tilsynet for å være korrupt, og jeg tar sterk avstand fra en slik påstand.

\section{Anne Alvik}

Oslo

Anne Alvik (f. 1937) er spesialist i samfunnsmedisin og tidligere helsedirektør. Ingen oppgitte interessekonflikter

\section{Litteratur}

1. Hamran 0. Et lite, korrupt gammelt vesen - apotekene og apotekloven av 2001. Tidsskr Nor Legeforen 2011: 131: 1311-5.

2. Norges offentlige utredninger. Rammevilkår for omsetning av legemidler. NOU 1997: 6 .

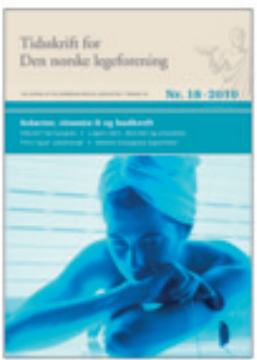

\section{Scientologiens hjernevask}

Jeg er helt enig med Vidje Hansen, som i Tidsskriftet nr. 2/2011 (1) kritiserer redaktøren for mangel på dømmekraft fordi innlegget til Hans-Erik Dyvik Husby kom på trykk i nr. 18/2010. Der refset han, som representant for Citizens Commission of Human Rights, psykiatrien i kraftige ordelag (2).

I lesingen av Dyvik Husby gikk mine tanker tilbake til 1980-årene, da jeg selv var medlem av scientologikirken, som Citizens Commission of Human Rights er en del av. Å lese dette var som et ekko fra fortiden, et hakk i platen. De samme ordene ble sagt den gang. Scientologikirken hevder at en av samfunnets verste fiender er psykiatrien. Når Dyvik Husby synes det er forunderlig at mennesker med psykiske problemer drøfter dem med sin fastlege, er dette i tråd med scientologenes tankegang. Mellom linjene sies det at fastlegen burde sende alle med psykiske lidelser til dem.

Scientologikirken mener selv de vet mest om sinnet - og har dermed alle svar. De hevder at det kun finnes én form for psykisk lidelse: Det er aberrasjon eller en aberrert tanke. Aberrasjon er avvik fra en rasjonell tanke eller rasjonell atferd. Aberrasjon benyttes om alle former for psykoser, nevroser, tvangstanker, tvangshandlinger og fortregninger. For å få orden på tankene igjen går man til scientologikirkens auditører for å bli auditert. En auditør bruker elektrometer (løgndetektor) som verktøy.

Det er vanskelig for meg å forstå at Dyvik Husby er så opptatt av vitenskapelig forskning. Det hadde vært interessant om han kunne vise til en forskningsartikkel der metoden som er forklart over er vitenskapelig bevist og at den hjelper for alle typer psykiske lidelser. Jeg for min del så aldri noe av den type lesestoff.

Ellers handler artikkelen for det meste om hvordan legemiddelindustrien hele tiden banker på fastlegens kontor og om kjøp og salg av piller. Når en scientolog skal hjelpe et menneske med problemer, handler det om å selge et kurs - og enda et nytt kurs. Det tar aldri slutt, og summene blir som kjent høyere og høyere. Kursene handler om å studere Hubbards tekster (3). Hvordan tror Dyvik Husby at en person som er dypt deprimert, har angst og søvnløshet, klarer å ha fokus på tekst etter tekst? Jo, scientologikirken vet svaret: En annen type kurs, selvfølgelig. Har man andre tanker enn de Hubbard tenkte, er man en fare for samfunnet $-\mathrm{i}$ begynnelsen av en aberrert tanke, og hvem vil vel det? Da får man en auditering eller en annen sjekk for å få tankene på rett kjøl igjen. Skremmende, og med rette kalt hjernevask. Dyvik Husby har ikke noe annet valg enn å si det de andre i menigheten sier. Med andre ord - han er fanget $\mathrm{i}$ systemet.

\section{Anne-Margrethe Hovet}

Oslo

Anne-Margrethe Hovet (f. 1959) er utdannet innen alternativ terapi lakupunktur, kinesiologi, bildeterapi). For tiden jobber hun som sekretær på Rikshospitalet og som bildeterapeut. Ingen oppgitte interessekonflikter.

\section{Litteratur}

1. Hansen V. Alvorlig svikt i redaktørens dømmekraft. Tidsskr Nor Legeforen 2011; 131: 110

2. Husby H-ED. Gjøkungen i medisinen. Tidsskr Nor Legeforen 2010; 130: 1892

3. Hubbard LR. Dianetikk. Oslo: New Era publications, 2007.

\section{Uspesifikke smerter gir uspesifikk behandling}

Erik L. Werner og medarbeidere går i Tidsskriftet nr. 15/2011 i rette med mine uttalelser om at ryggpasienten ikke blir tatt på alvor i de nasjonale retningslinjene (1-3). I retningslinjene anføres det at $85 \%$ av ryggpasientene har kun uspesifikke ryggsmerter.

«Uspesifikke smerter» åpner opp for uspesifikk behandling. Det ser vi ikke minst innen ryggmedisinen, der ingen behandling hos $85 \%$ av ryggpasientene, etter de samme nasjonale retningslinjene, tydeligvis ikke er bedre eller verre enn annen håndtering. Det tjener ikke pasienten, men muligens noen behandlere.

Problemet er at forfatterne tydeligvis ikke selv mener at disse ryggsmertene er uspesifikke. Brox har vært én av initiativtakerne og inspiratorene for to større longitudinelle studier om bakre fiksasjon, alternativt skiveprotese kontra konservativ behandling ved degenerativ skivelidelse lumbalt $(4,5)$. Man skulle tro at gjennomføring av to så vidt store, ressurskrevende forskningsprosjekter med betydelige kirurgiske inngrep bør komme som et resultat av at forfatterne selv har en formening om at disse ryggsmertene skyldes nettopp de degenerative skiveforandringene? Hvorfor gjelder ikke en tilsvarende åpenhet ovenfor ryggpasienter med slik lidelse? Degenerative skiveforandringer inngår $\mathrm{i}$ «uspesifikke ryggsmerter» $\mathrm{i}$ de nasjonale retningslinjene.

Vi må ta oss tid til å undersøke - lytte til pasientens egne beretninger om smertelokalisasjon, -varighet, -karakter, -provokasjon og -lindring. Vi må foreta en standard klinisk ryggundersøkelse og gjerne gå gjennom MR-bildene sammen med pasienten.

Endelig må også psykososiale forhold i tas med i vurdering av tilstanden. Da kan vi etter min mening hjelpe langt flere enn de $15 \%$ som de nasjonale retningslinjene mener vi bør være fornøyd med å hjelpe.

Ryggmedisinen sliter med rekruttering til faget og ryggforskningen nå også med troverdigheten etter at det nylig er avdekket en rekke tilfeller av økonomisk samrøre mellom industrien og deler av det ortopediske fagmiljøet i USA (6) La ikke ryggpasienten lide mer enn nødvendig under dette. Mens vi i det stille bidrar til å eliminere generelle, forvirrende og inkonsekvente nasjonale retningslinjer, er tiden overmoden for en ryggbehandling med noe større grad av differensiering og presisjon.

\section{Håkon Lie \\ Rygg-og nakkepoliklinikken Oslo}

Håkon Lie (f. 1946) er spesialist i fysikalsk medisin og rehabilitering og i nevrologi. Ingen oppgitte interessekonflikter. 